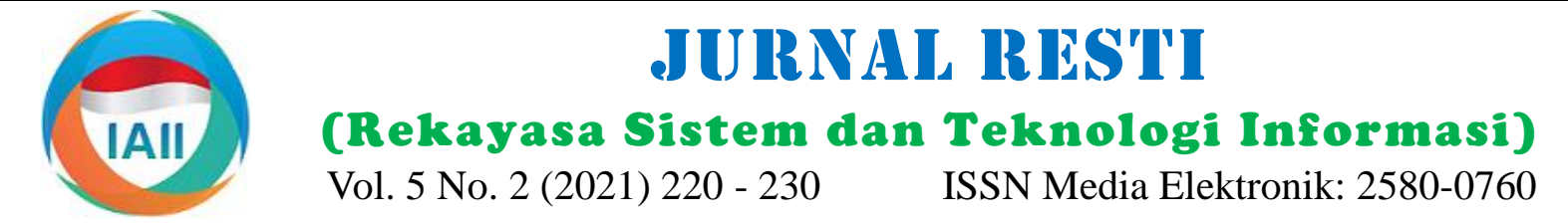

\title{
Prediksi Jumlah Produksi Akibat Penyebaran Covid-19 Menggunakan Metode Fuzzy Takagi-Sugeno
}

\author{
Khofifah Putriyani ${ }^{1}$, Tenia Wahyuningrum ${ }^{2}$, Yogo Dwi Prasetyo ${ }^{3}$ \\ 1,2,3 Teknik Informatika, Fakultas Informatika, Institut Teknologi Telkom Purwokerto \\ ${ }^{1} 17102131 @$ ittelkom-pwt.ac.id, ${ }^{2}$ tenia@ ittelkom-pwt.ac.id, ${ }^{3}$ yogo@ ittelkom-pwt.ac.id
}

\begin{abstract}
Global Bakery is a food company engaged in bread production that is having difficulty determining how much bread will be produced in the event of a pandemic. This study aims to help predict the amount of bread that will be produced during a pandemic. With the benefit of making it easier for companies to determine the amount of bread to be produced. Data obtained from Global Bakery and the official website of Covid-19 Bekasi Regency from March 20, 2020 to April 20, 2020. The author uses the Fuzzy Takagi-Sugeno method to predict the amount of bread that must be produced by Global Bakery during a pandemic with the following stages: fuzzification, rule formation, calculating a-predicate and zi value, then calculating defuzification. Then an evaluation is carried out using the Mean Absolute Percentage Error (MAPE). This study uses Matlab's GUI tools in implementing the Predictor program. The Fuzzy Takagi-Sugeno method is able to predict the amount of bread production at Global Bakery with optimal results, where if the sales are 180 pieces, the remaining sales are 289, and the number of positive cases of Covid-19 is 6 people with the actual production number of 469 pieces, then The prediction results obtained were 347 units. The results of the calculations that have been done obtained the results of accuracy with a good category, namely with a MAPE value of $18.6 \%$.
\end{abstract}

Keywords: production, food, sugeno, Covid-19, MAPE

\begin{abstract}
Abstrak
Global Bakery adalah sebuah perusahaan makanan yang bergerak di bidang produksi roti yang mengalami kesulitan untuk menentukan berapa banyak roti yang akan diproduksi saat terjadi pandemi. Penentuan jumlah roti yang akan diproduksi membutuhkan pertimbangan matang karena pandemi Covid-19 yang terus berkembang. Penelitian ini memilki tujuan untuk membantu memprediksi jumlah roti yang akan diproduksi saat terjadi pandemi. Dengan manfaat untuk mempermudah perusahaan dalam menentukan banyaknya roti yang akan diproduksi. Data diperoleh dari Global Bakery dan website resmi Covid-19 Kabupaten Bekasi sebanyak 32 data dari tanggal 20 Maret 2020 hingga 20 April 2020. Data tersebut digunakan sebagai masukan dari logika fuzzy. Penelitian ini menggunakan metode Fuzzy Takagi-Sugeno untuk memprediksi jumlah roti yang harus diproduksi oleh Global Bakery saat terjadi pandemi dengan tahapan sebagai berikut: fuzzifikasi, pembentukan aturan, menghitung $a$-predikat dan nilai $\mathrm{z}_{\mathrm{i}}$, kemudian menghitung defuzifikasi untuk mendapatkan hasil digunakan sebagai alternatif untuk menentukan jumlah roti yang akan diproduksi. Kemudian dilakukan evaluasi dengan menggunakan Mean Absolute Percentage Error (MAPE). Penelitian ini menggunakan tools GUI Matlab dalam mengimplementasikan program Prediktor. Metode Fuzzy Takagi-Sugeno mampu memprediksi jumlah produksi roti pada Global Bakery dengan hasil yang optimal, dimana jika penjualan sebanyak 180 buah, sisa penjualan sebanyak 289 buah, dan jumlah kasus positif Covid-19 sebanyak 6 orang dengan jumlah produksi aktual sebanyak 469 buah, maka diperoleh hasil prediksi jumlah produksi sebanyak 347 buah. Hasil prediksi tersebut yang dijadikan sebagai acuan penentu banyaknya roti yang akan diproduksi saat pandemi. Hasil perhitungan yang telah dilakukan diperoleh hasil akurasi dengan kategori baik yaitu dengan nilai MAPE sebesar 18,6\%.
\end{abstract}

Kata kunci: : produksi, pangan, sugeno, Covid-19, MAPE

\section{Pendahuluan}

Badan Kesehatan Dunia (WHO) menyatakan bahwa virus corona atau Covid-19 ditetapkan sebagai pandemi global, karena penyebaran yang sangat cepat ke seluruh penjuru dunia, jumlah kasus dan kematian yang terus meningkat serta kurangnya terapi dan vaksin [1]. Berdasarkan data WHO jumlah kasus kumulatif Covid19 per-tanggal 2 April 2020 mencapai 902.496 kasus [2]. 
Pemerintah Indonesia mengambil kebijakan guna kelompok kategori gizi balita yang digunakan sebanyak meminimalisir penyebaran Covid-19 dengan 5 kategori [11].

menerapkan social distancing (jaga jarak sosial) dan physical distancing (jaga jarak antar orang) kepada masyarakat. Pembatasan Sosial Berskala Besar (PSBB) juga diterapkan pada wilayah jabodetabek [3]. Penerapan kebijakan tersebut menimbulkan dampak buruk seperti kerugian ekonomi, pengangguran, kelangkaan makanan dan kesejahteraan masyarakat menurun [4][5]. Aktivitas dan pergerakan masyarakat di Jabodetabek dan kota-kota besar terjadi penurunan drastis setelah adanya kebijakan tersebut. Bagi entitas usaha, adanya PSBB dapat menimbulkan kerugian, turunnya pendapatan karena penjualan yang menurun. Kerugian yang timbul akan menyebabkan modal perusahaan terkuras hingga skala usaha menyusu bahkan bangkrut [6].

Salah satu perusahaan roti yang berada di Bekasi yaitu Global Bakery merasakan imbas dari adanya pandemi Covid-19. Global Bakery mengalami masalah tentang perkembangan penjualan roti yang tidak seimbang dengan jumlah produksi sejak adanya pandemi Covid19. Perusahaan industri ini bergerak dibidang produksi pangan yang memiliki jangka waktu konsumsi maka perusahaan harus dapat menentukan jumlah produk yang akan diproduksi dengan tepat agar produk yang tersisa tidak terbuang karena habis masa konsumsi [7][8]. Adanya penentuan jumlah produksi yang tepat
sehingga perusahaan tidak mengalami kerugian, dan sehingga perusahaan tidak mengalami kerugian, dan
adanya permasalahan kelebihan atau kekurangan produksi sangat berpengaruh terhadap pendapatan perusahaan. Usaha untuk mengatasi masalah tersebut
diperlukan suatu prediksi jumlah produksi roti dengan tepat [9].

Ferly Ardhy dan Dwi Marisa Efendi melakukan prediksi jumlah pemesanan Roti Jordan dengan membandingkan dua metode Fuzzy Inference System yaitu Tsukamoto dan Sugeno, untuk mengetahui metode manakah yang tepat digunakan untuk memprediksi dan manakah yang
memiliki nilai rata-rata absolute error lebih kecil. Hasil perbandingan kedua metode tersebut setelah dilakukan perhitungan didapatkan bahwa prediksi menggunakan metode Sugeno lebih baik dibandingkan metode [18]

Tsukamoto dengan rata-rata absolute error metode Sugeno sebesar $0,01776 \%$, sedangkan metode Tsukamoto sebesar 0,50428\% [10].

Surhajito, Jimmy, dan Abba Suganda Girsang (absa Suganda Girsang keseluruhan yang dilakukan dalam prediksi jumlah melakukan penelitian pada tahun 2017. Penelitian produksi roti saat pandemi [7]. Adapun tahapan atau alur tersebut berfokus pada penentuan status gizi balita dari penelitiani ini diawali dengan studi pendahuluan, berdasarkan tinggi, berat, dan usia agar dapat kemudian ketahap pengumpulan data hingga mengontrol dan menjaga kesehatan balita yang pengolahan data. Setelah tahap pengolahan data selesai, membutuhkan gizi untuk tumbuh kembang. Metode masuk ketahap penerapan Fuzzy, dalam metode Fuzzy yang digunakan untuk mendukung sistem pada terdiri dari 4 tahap, yaitu: penentuan variabel fuzzy, penelitian tersebut adalah Fuzzy Sugeno. Hasil pembentukan aturan fuzzy, inferensi fuzzy, dan penelitian membuktikan bahwa metode Fuzzy Sugeno defuzzifikasi. Setelah dilakukan penerapan Fuzzy, maka memiliki akurasi tinggi dan mendekati ideal karena didapatkan hasil ramalan dari defuzzifikasi.

DOI: https://doi.org/10.29207/resti.v5i2.2973

Lisensi: Creative Commons Attribution 4.0 International (CC BY 4.0) 


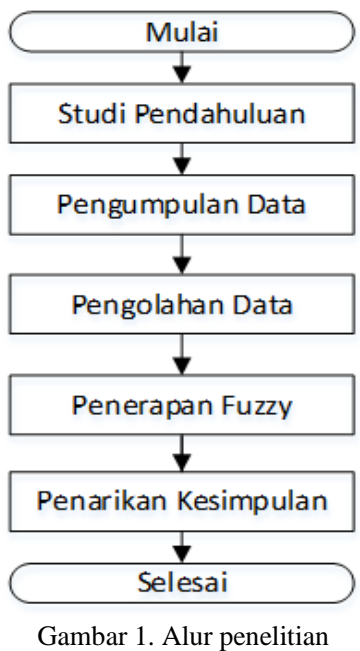

\subsection{Studi Pendahuluan}

Tahapan ini berisi penentuan masalah, pencarian dan pengkajian literatur dengan mengumpulkan artikel, jurnal, dan prosiding. Kemudian menemukan makalah yang berkaitan dengan persoalan penelitian. Kemudian melakukan wawancara dengan pihak Global Bakery mengenai persoalan produksi. Kemudian melakukan studi penelitian terdahulu yang masih berkaitan dan dijadikan sebagai acuan penelitian ini.

\subsection{Pengumpulan Data}

Data bersumber dari Global Bakery dan website resmi Covid-19 Kabupaten Bekasi. Data Global Bakery yang dibutuhkan untuk penelitian ini meliputi data penjualan, data sisa penjualan, dan data produksi. Data Covid-19 meliputi jumlah kasus kumulatif penyebaran yang terjadi di Bekasi.

\subsection{Pengolahan Data}

Pengolahan data yang dilakukan dalam penelitian ini yaitu data yang telah didapatkan dari sumber lalu diolah menggunakan metode normalisasi untuk memperoleh data yang sesuai. Sehingga data yang didapatkan sebanyak 32 record data.

\subsection{Penerapan Fuzzy}

Penerapan fuzzy berisi proses penerapan metode yang digunakan dalam penelitian ini. Berikut proses penerapan fuzzy [19] :

Menentukan variabel fuzzy, Variabel yang digunakan dalam penelitian ini terdiri dari: 3 variabel input, variabel jual, variabel sisa, dan variabel Covid-19, serta variabel output terdapat 1 variabel yaitu: variabel produksi. Setelah menentukan variabel kemudian membentuk himpunan fuzzy. Variabel jual memiliki himpunan sedikit dan banyak, variabel sisa memiliki himpunan sedikit dan banyak, variabel Covid-19 memiliki himpunan berkurang dan bertambah, serta variabel produksi memiliki himpunan sedikit dan banyak.
Membentuk aturan fuzzy, Pembentukan aturan fuzzy melibatkan semua variabel yang sudah ditentukan sebelumnya.

Inferensi fuzzy, Berdasarkan aturan yang sudah dibentuk, akan digunakan untuk menentukan nilai $\alpha$ (nilai keanggotaan dari setiap aturan) dan $z$ (nilai perkiraan barang yang akan diproduksi dari setiap aturan).

Nilai $z$ dari setiap aturan didapatkan berdasarkan ratarata banyaknya roti yang diproduksi per hari dan memenuhi kriteria dari aturan yang sudah ditentukan.

Defuzzifikasi. Metode yang digunakan dalam defuzzifikasi adalah center of singleton seperti pada persamaan (1) berikut :

$$
Z^{*}=\frac{\propto 1 * Z 1+\propto 2 * Z 2+\cdots+\propto 7 * Z 7+\propto 8 * Z 8}{\propto 1+\propto 2+\cdots+\propto 7+\propto 8}
$$

Kesimpulan penelitian ini diambil dari hasil perhitungan prediksi menggunakan metode Fuzzy Takagi Sugeno yaitu hasil dari proses defuzzifikasi. Hasil tersebut yang nantinya digunakan sebagai acuan dalam menentukan banyaknya jumlah roti yang akan diproduksi oleh Global Bakery pada saat pandemi Covid-19.

Hasil perhitungan prediksi menggunakan metode Fuzzy Takagi Sugeno yang digunakan sebagai acuan kemudian dilakukan evaluasi dengan menunjukkan tingkat kesalahan metode Fuzzy Takagi Sugeno dalam peramalan dibandingkan dengan nilai sebenarnya menggunakan Mean Absolute Percentage Error (MAPE). Nilai MAPE ditunjukkan dalam persentase [13]. Rumus MAPE sebagai berikut [20]:

$$
M A P E=\frac{\sum \frac{|\hat{y} t-y t|}{y t}}{n} \times 100 \%
$$

dengan $\hat{y} t$ adalah nilai prediksi pada periode $t, y t$ adalah nilai aktual pada periode $t$, dan $n$ adalah banyaknya data [13]. Tabel 1 menunjukkan penjelasan tingkat akurasi dari nilai MAPE, berikut:

Tabel 1. Evaluasi prediksi dengan nilai MAPE

\begin{tabular}{cc}
\hline Nilai MAPE & Akurasi Prediksi \\
\hline MAPE $\leq 10 \%$ & Tinggi \\
$10 \%<$ MAPE $\leq 20 \%$ & Baik \\
$20 \%<$ MAPE $\leq 50 \%$ & Masuk Akal \\
MAPE $\geq 50 \%$ & Rendah \\
\hline
\end{tabular}

\section{Hasil dan Pembahasan}

3.1. Metode Fuzzy Takagi-Sugeno dalam Memprediksi Jumlah Produksi

Data yang telah didapatkan ditunjukkan pada Tabel 2, dampak pandemi yang cukup terlihat pada saat awal masuknya covid-19 di Indonesia yaitu bulan Maret 2020, seperti yang dijelaskan pada penelitian mengenai dampak covid-19 terhadap ekonomi di Indonesia [18] : 
Tabel 2. Data bulan Maret - April 2020

\begin{tabular}{|c|c|c|c|c|}
\hline Tanggal & $\begin{array}{c}\text { Produksi } \\
\text { (buah) }\end{array}$ & $\begin{array}{l}\text { Penjualan } \\
\text { (buah) }\end{array}$ & $\begin{array}{c}\text { Sisa } \\
\text { (buah) }\end{array}$ & $\begin{array}{c}\text { Covid-19 } \\
\text { (orang) }\end{array}$ \\
\hline 20-Mar-20 & 469 & 180 & 289 & 6 \\
\hline 21-Mar-20 & 432 & 350 & 82 & 6 \\
\hline 22-Mar-20 & 544 & 339 & 205 & 6 \\
\hline 23-Mar-20 & 479 & 159 & 320 & 8 \\
\hline 24-Mar-20 & 371 & 126 & 245 & 15 \\
\hline 25-Mar-20 & 265 & 136 & 129 & 14 \\
\hline 26-Mar-20 & 310 & 131 & 179 & 15 \\
\hline 27-Mar-20 & 216 & 193 & 23 & 18 \\
\hline 28-Mar-20 & 651 & 203 & 448 & 20 \\
\hline 29-Mar-20 & 255 & 237 & 18 & 20 \\
\hline 30-Mar-20 & 630 & 139 & 491 & 20 \\
\hline 31-Mar-20 & 225 & 136 & 89 & 22 \\
\hline 1-Apr-20 & 570 & 181 & 389 & 23 \\
\hline 2-Apr-20 & 570 & 192 & 378 & 23 \\
\hline 3-Apr-20 & 840 & 228 & 612 & 24 \\
\hline 4-Apr-20 & 525 & 183 & 342 & 24 \\
\hline 5-Apr-20 & 420 & 289 & 131 & 27 \\
\hline 6-Apr-20 & 435 & 122 & 313 & 30 \\
\hline 7-Apr-20 & 285 & 147 & 138 & 33 \\
\hline 8-Apr-20 & 435 & 149 & 286 & 35 \\
\hline 9-Apr-20 & 330 & 143 & 187 & 35 \\
\hline 10-Apr-20 & 630 & 144 & 486 & 41 \\
\hline 11-Apr-20 & 720 & 252 & 468 & 42 \\
\hline 12-Apr-20 & 285 & 285 & 0 & 43 \\
\hline 13-Apr-20 & 555 & 132 & 423 & 46 \\
\hline 14-Apr-20 & 300 & 92 & 208 & 46 \\
\hline 15-Apr-20 & 600 & 122 & 478 & 50 \\
\hline 16-Apr-20 & 225 & 102 & 123 & 54 \\
\hline 17-Apr-20 & 540 & 90 & 450 & 59 \\
\hline 18-Apr-20 & 285 & 148 & 137 & 60 \\
\hline 19-Apr-20 & 495 & 245 & 250 & 60 \\
\hline 20-Apr-20 & 555 & 114 & 441 & 62 \\
\hline
\end{tabular}

\subsubsection{Fuzzifikasi}

Tahap ini menentukan variabel fuzzy, himpunan fuzzy, semesta pembicaraan, dan domain. Tabel 3 menjelaskan mengenai himpunan fuzzy, semesta pembicaraan, domain, dan fungsi keanggotaan.

Tabel 3. Pembentukan himpunan fuzzy variabel input dan output

\begin{tabular}{|c|c|c|c|}
\hline Variabel & $\begin{array}{c}\text { Himpunan } \\
\text { Fuzzy }\end{array}$ & $\begin{array}{c}\text { Semesta } \\
\text { Pembicaraan }\end{array}$ & Domain \\
\hline \multirow{2}{*}{ Penjualan [x] } & Sedikit & \multirow{2}{*}{ [50 400] } & {$\left[\begin{array}{ll}90 & 220\end{array}\right]$} \\
\hline & Banyak & & {$\left[\begin{array}{lll}2 & 20 & 350\end{array}\right]$} \\
\hline \multirow{2}{*}{$\begin{array}{c}\text { Sisa } \\
\text { Penjualan }[y]\end{array}$} & Sedikit & \multirow{2}{*}[\begin{array}{ll}{0}&{650}\end{array}]{} & {$\left[\begin{array}{ll}0 & 306\end{array}\right]$} \\
\hline & Banyak & & [306 612] \\
\hline \multirow{2}{*}{ Covid-19 [z] } & Berkurang & \multirow{2}{*}{$\begin{array}{ll}0 & 70]\end{array}$} & {$\left[\begin{array}{ll}6 & 34\end{array}\right]$} \\
\hline & Bertambah & & [34 62] \\
\hline \multirow{2}{*}{ Produksi [v] } & Sedikit & \multirow{2}{*}{ [200 850] } & [216 528] \\
\hline & Banyak & & {$\left[\begin{array}{lll}528 & 840\end{array}\right]$} \\
\hline
\end{tabular}

penjualan, sisa penjualan, Covid-19, dan produksi akan direpresentasikan berdasarkan data yang telah didapatkan sebagai berikut:

Variabel penjualan didefinisikan dalam dua himpunan fuzzy yaitu sedikit dan banyak. Variabel penjualan direpresentasikan menggunakan bentuk kurva bahu kiri untuk himpunan fuzzy sedikit dan bahu kanan untuk himpunan fuzzy banyak. Gambar 2 menunjukkan variabel penjualan.

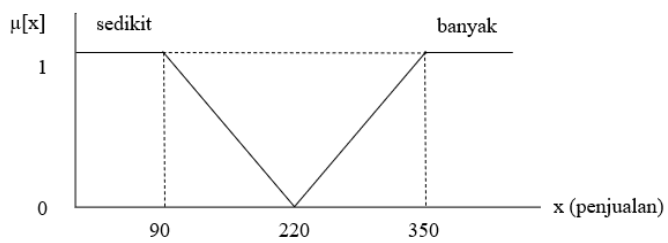

Gambar 2. Kurva himpunan fuzzy pada variabel penjualan

Fungsi keanggotaan variabel penjualan ditunjukkan pada persamaan berikut:

$$
\begin{gathered}
\mu_{\text {jualsedikit }}[x]=\left\{\begin{array}{cc}
1, & x \leq 90 \\
\frac{220-x}{220-90}, & 0 \leq x \leq 220 \\
0, & x \geq 220
\end{array}\right. \\
\mu_{\text {jualBanyak }}[x]=\left\{\begin{array}{cc}
0, & x \leq 220 \\
\frac{x-220}{350-220}, & 20 \leq x \leq 350 \\
1, & x \geq 350
\end{array}\right.
\end{gathered}
$$

Variabel sisa penjualan didefinisikan dua himpunan fuzzy yaitu sedikit dan banyak. Variabel sisa penjualan direpresentasikan dengan bentuk kurva linear kiri untuk himpunan fuzzy sedikit dan kurva bahu kanan untuk himpunan fuzzy banyak. Berikut bentuk kurva dari variabel sisa penjualan ditunjukkan pada Gambar 3:

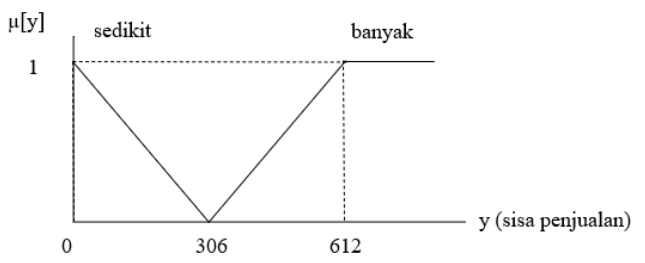

Gambar 3. Kurva himpunan fuzzy pada variabel sisa penjualan

Berikut persamaan fungsi keanggotaan dari variabel sisa penjualan :

$$
\begin{gathered}
\mu_{\text {sisasedikit }}[y]=\left\{\begin{array}{cc}
1, & y \leq 0 \\
\frac{306-y}{306-0}, & 0 \leq y \leq 306 \\
0, & y \geq 306
\end{array}\right. \\
\mu_{\text {sisaBanyak }}[y]=\left\{\begin{array}{cc}
0, & y \leq 306 \\
\frac{y-306}{612-306}, & 306 \leq y \leq 612 \\
1, & y \geq 612
\end{array}\right.
\end{gathered}
$$

Selanjutnya menentukan fungsi keanggotaan untuk Variabel Covid-19 didefinisikan dua himpunan fuzzy setiap variabel, kemudian menghitung nilai derajat yaitu berkurang dan bertambah. Variabel covid-19 keanggotaan berdasarkan fungsi keanggotaan. direpresentasikan pada kurva bahu kiri untuk himpunan Himpunan fuzzy dan fungsi keanggotaan dari variabel fuzzy berkurang dan kurva bahu kanan untuk himpunan

DOI: https://doi.org/10.29207/resti.v5i2.2973 
fuzzy bertambah. Kurva variabel covid-19 ditunjukkan pada Gambar 4 sebagai berikut:

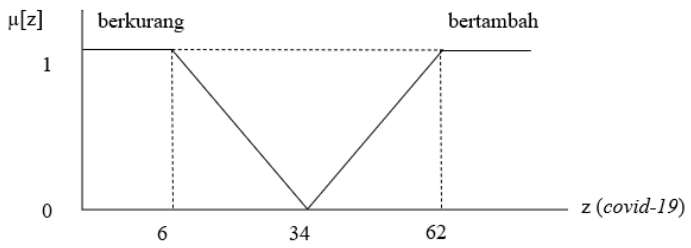

Gambar 4. Kurva himpunan fuzzy pada variabel Covid-19

Fungsi keanggotaan dari variabel covid-19 ditunjukkan pada persamaan berikut:

$\mu_{\text {covidBerkurang }}[z]=\left\{\begin{array}{cc}1, & z \leq 6 \\ \frac{34-z}{34-6}, & 6 \leq z \leq 34 \\ 0, & z \geq 34\end{array}\right.$

$\mu_{\text {covidBertambah }}[z]=\left\{\begin{array}{cc}0, & z \leq 34 \\ \frac{z-34}{62-34}, & 4 \leq z \leq 62 \\ 1, & z \geq 62\end{array}\right.$

Variabel Produksi didefinisikan dua himpunan fuzzy yaitu sedikit dan banyak. Variabel produksi direpresentasikan pada kurva bahu kiri untuk himpunan fuzzy sedikit dan kurva bahu kanan untuk himpunan fuzzy banyak. Kurva dari variabel produksi ditunjukkan pada Gambar 5 berikut:

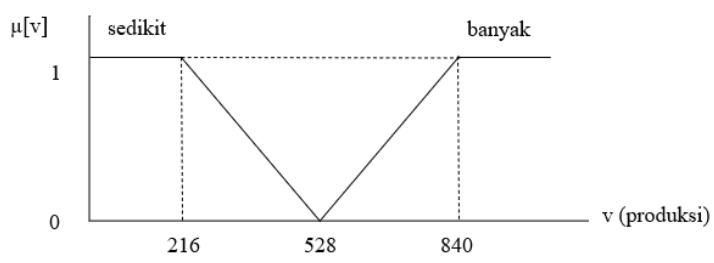

Gambar 5. Kurva himpunan fuzzy pada variabel produksi

Fungsi keanggotaan dari variabel produksi ditunjukkan pada persamaan berikut:

$\mu_{\text {prodsedikit }}[v]=\left\{\begin{array}{cc}1, & v \leq 216 \\ \frac{528-v}{528-216}, & 216 \leq v \leq 528 \\ 0, & v \geq 528\end{array}\right.$

$\mu_{\text {prodBanyak }}[v]=\left\{\begin{array}{cc}0, & v \leq 528 \\ \frac{v-528}{840-528}, & 528 \leq v \leq 840 \\ 1, & v \geq 840\end{array}\right.$

\subsubsection{Pembentukan Aturan}

Setelah menentukan fungsi keanggotaan setiap variabel, selanjutnya yaitu membentuk aturan-aturan logika fuzzy. Tahap penyusunan basis aturan, yaitu aturan-aturan yang berupa implikasi fuzzy, menyatakan hubungan yang melibatkan variabel linguistik dari variabel input dan output dengan ketentuan $2^{n}$ dimana $\mathrm{n}$ adalah jumlah variabel input yaitu 3 sehingga $2^{3}$ dihasilkan 8 rule seperti yang tertera dalam Tabel 4 .
Tabel 4. Tabel aturan fuzzy berupa fungsi implikasi fuzzy

\begin{tabular}{ccccc}
\hline Rule & Penjualan & Sisa & Covid-19 & Produksi \\
\hline R1 & Sedikit & Sedikit & Berkurang & Sedikit \\
R2 & Sedikit & Sedikit & Bertambah & Sedikit \\
R3 & Sedikit & Banyak & Berkurang & Banyak \\
R4 & Sedikit & Banyak & Bertambah & Banyak \\
R5 & Banyak & Sedikit & Berkurang & Sedikit \\
R6 & Banyak & Sedikit & Bertambah & Sedikit \\
R7 & Banyak & Banyak & Berkurang & Banyak \\
R8 & Banyak & Banyak & bertambah & Banyak \\
\hline
\end{tabular}

Setelah mengetahui fungsi implikasi selanjutnya akan di cari bentuk produksi menggunakan rumus Model Fuzzy Sugeno Orde Nol dengan persamaan berikut:

if ( $x 1$ is $A 1)$ o( $x 2$ is $A 2)$ o( $x 3$ is $A 3)$ then $z=k$

A adalah sebagai himpunan fuzzy dan $k$ adalah konstanta (tegas) sebagai konsekuen. Berdasarkan persamaan (11), maka didapatkan aturan yang baru dengan variabel produksi berupa $z=k$. Untuk mendapatkan nilai $k$, maka dilakukan perhitungan rata-rata nilai produksi roti per hari, dengan memperhatikan domain setiap himpunan fuzzy dan aturan baru yang telah dibentuk pada Tabel 4 .

Misalkan, data produksi pada tanggal 20 April memiliki data penjualan sebesar 114 , data sisa penjualan sebesar 441, data Covid-19 sebesar 62, dan data produksi sebesar 555. Kemudian berdasarkan domain yang tertera pada Tabel 4.3 disimpulkan bahwa dengan data penjualan 114 termasuk himpunan fuzzy penjualan sedikit, data sisa penjualan 441 termasuk himpunan fuzzy sisa penjualan banyak, dan data Covid-19 62 termasuk himpunan fuzzy Covid-19 bertambah. Berdasarkan Tabel Aturan Baru, maka data produksi tanggal 20 April masuk ke dalam perhitungan rata-rata produksi untuk aturan ke-4, dan seterusnya. Kemudian hitung nilai rata-rata produksi berdasarkan total produksi dibagikan $n$ atau banyaknya record data yang ada, perhitungan nilai rata-rata produksi sebagai nilai $z=k$ atau nilai konsekuen dari aturan yang dibentuk, sehingga didapatkan aturan baru sebagai berikut:

[R1] IF Penjualan Sedikit AND Sisa Penjualan Sedikit AND Covid-19 Berkurang THEN Produksi = 347,3

[R2] IF Penjualan Sedikit AND Sisa Penjualan Sedikit AND Covid-19 Bertambah THEN Produksi $=270$ [R3] IF Penjualan Sedikit AND Sisa Penjualan Banyak AND Covid-19 Berkurang THEN Produksi $=589,2$

[R4] IF Penjualan Sedikit AND Sisa Penjualan Banyak AND Covid-19 Bertambah THEN Produksi = 576

[R5] IF Penjualan Banyak AND Sisa Penjualan Sedikit AND Covid-19 Berkurang THEN Produksi $=330,2$ [R6] IF Penjualan Banyak AND Sisa Penjualan Sedikit AND Covid-19 Bertambah THEN Produksi $=390$ [R7] IF Penjualan Banyak AND Sisa Penjualan Banyak AND Covid-19 Berkurang THEN Produksi $=840$ [R8] IF Penjualan Banyak AND Sisa Penjualan Banyak AND Covid-19 Bertambah THEN Produksi $=720$

DOI: https://doi.org/10.29207/resti.v5i2.2973

Lisensi: Creative Commons Attribution 4.0 International (CC BY 4.0) 
3.2. Pengujian Kasus Metode Takagi-Sugeno dalam Memprediksi Jumlah Produksi

Pengujian secara manual dilakukan pada 32 data yang telah didapatkan, berikut contoh pengujian data tanggal 20 Maret 2020:

Nilai Input penjualan sebesar 180, nilai input sisa sebanyak 289, dan nilai input Covid-19 sebanyak 6, Perhitungan derajat keanggotaan setiap variabel dalam setiap himpunan menggunakan persamaan (3) sampai (8).

Variabel penjualan, didefinisikan pada himpunan fuzzy sedikit dan sedang. Setiap himpunan fuzzy memiliki interval keanggotaan seperti pada Gambar 6.

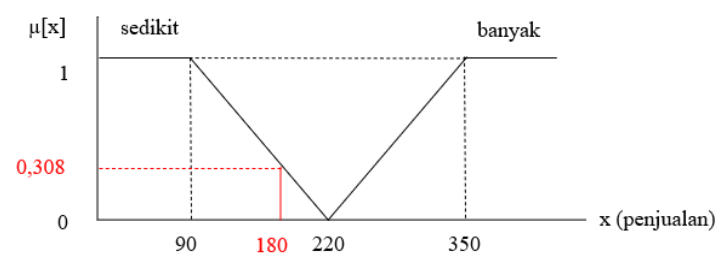

Gambar 6. Contoh kurva himpunan fuzzy variabel penjualan

Dengan tingkat keanggotaan berdasarkan fungsi pada persamaan (3) dan (4), sehingga diperoleh sebagai berikut:

$\mu_{\text {jualSedikit }}[180]=\frac{220-180}{220-90}=0,308$
$\mu_{\text {jualBanyak }}[180]=0$

berarti bahwa penjualan dapat dikatakan sedikit dengan derajat keanggotaan 0,308 dan dikatakan banyak dengan derajat keanggotaan 0 .

Variabel sisa jual, didefinisikan pada himpunan fuzzy sedikit dan sedang. Setiap himpunan fuzzy memiliki $Z$ interval keanggotaan seperti pada Gambar 7.

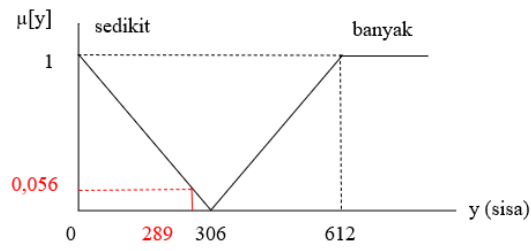

Gambar 7. Contoh kurva himpunan fuzzy variabel sisa jual dimana nilai produksi yang sebenarnya adalah 469 .

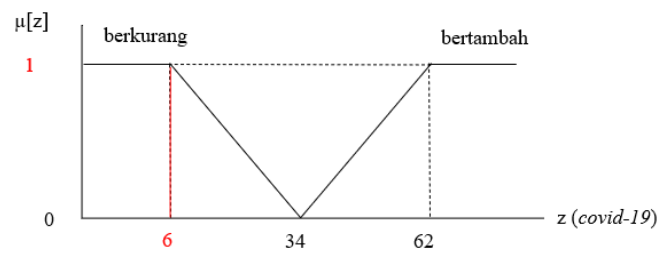

Gambar 8. Contoh kurva himpunan fuzzy variabel Covid-19

Tingkat keanggotaan yang didapatkan berdasarkan persamaan fungsi (7) dan (8), sebagai berikut:

$\mu_{\text {covidBerkurang }}[6]=\frac{34-6}{34-6}=1$

$\mu_{\text {covidBertambah }}[6]=0$

dapat dikatakan bahwa kasus covid-19 berkurang dengan derajat keanggotaan 1 dan dikatakan bertambah dengan derajat keanggotaan 0 .

Kemudian mencari $\alpha$-predikat setiap aturan dengan fungsi implikasi, mengambil nilai minimal dari elemen himpunan fuzzy terkait, dan nilai $\mathrm{Z}_{\mathrm{i}}$ diambil dari nilai produksi pada setiap aturan, sebagai berikut :

[R1] IF Penjualan Sedikit AND Sisa Penjualan Sedikit AND Covid-19 Berkurang THEN Produksi $=347,3$

$\alpha$-predikat $_{1} \quad=\min \left(\mu_{\text {jualSedikit }}[180] ; \mu_{\text {sisaSedikit }}[289]\right.$;

$\left.\mu_{\text {covidBerkurang }}[6]\right)$

$=\min (0,308 ; 0,056 ; 1)$

$=0,056$

$\mathrm{Z}_{1} \quad=347,3$

[R2] IF Penjualan Sedikit AND Sisa Penjualan Sedikit AND Covid-19 Bertambah THEN Produksi $=270$

$\alpha$-predikat $_{2} \quad=\min \left(\mu_{\text {jualSedikit }}[180] ; \mu_{\text {sisaSedikit }}[289]\right.$;

$\left.\mu_{\text {covidBertambah }}[6]\right)$

$=\min (0,308 ; 0,056 ; 0)$

$=0$

$=270$

[R3] IF Penjualan Sedikit AND Sisa Penjualan Banyak AND Covid-19 Berkurang THEN Produksi = 589,2

$\alpha$-predikat $_{3} \quad=\min \left(\mu_{\text {jualSedikit }}[180] ; \mu_{\text {sisaBanyak }}[289]\right.$;

$\left.\mu_{\text {covidBerkurang }}[6]\right)$

$=\min (0,308 ; 0 ; 1)$

$=0$

$\mathrm{Z}_{3} \quad=589,2$

[R4] IF Penjualan Sedikit AND Sisa Penjualan Banyak AND Covid-19 Bertambah THEN Produksi $=576$

Berikut tingkat keanggotaan yang didapatkan $\alpha$-predikat $4=\min \left(\mu_{\text {jualSedikit }}[180] ; \mu_{\text {sisaBanyak }}[289]\right.$; berdasarkan persamaan fungsi (5) dan (6) :

$\mu_{\text {sisaSedikit }}[289]=\frac{306-289}{306-0}=0,056$

$\mu_{\text {sisaBanyak }}[289]=0$

$\left.\mu_{\text {covidBertambah }}[6]\right)$

$=\min (0,308 ; 0 ; 0)$

$=0$

$\mathrm{Z}_{4} \quad=589,2$

dapat dikatakan bahwa sisa jual sedikit dengan derajat [R5] IF Penjualan Banyak AND Sisa Penjualan Sedikit keanggotaan 0,056 dan dikatakan banyak dengan derajat keanggotaan 0 .

Variabel Covid-19, didefinisikan pada himpunan fuzzy sedikit dan sedang. Setiap himpunan fuzzy memiliki interval keanggotaan seperti pada Gambar 8.

AND Covid-19 Berkurang THEN Produksi $=330,2$

$\alpha$-predikat $_{5} \quad=\min \left(\mu_{\text {jualBanyak }}[180] ; \mu_{\text {sisaSedikit }}[289]\right.$; $\left.\mu_{\text {covidBerkurang }}[6]\right)$

$=\min (0 ; 0,056 ; 1)$

$=0$

$\mathrm{Z}_{5} \quad=330,2$ 
[R6] IF Penjualan Banyak AND Sisa Penjualan Sedikit AND Covid-19 Bertambah THEN Produksi $=390$

$\alpha$-predikat $_{6} \quad=\min \left(\mu_{\text {jualBanyak }}[180] ; \mu_{\text {sisaSedikit }}[289]\right.$;

$\left.\mu_{\text {covidBertambah }}[6]\right)$

$=\min (0 ; 0,056 ; 0)$

$=0$

$\mathrm{Z}_{6}$

$$
=390
$$

[R7] IF Penjualan Banyak AND Sisa Penjualan Banyak AND Covid-19 Berkurang THEN Produksi $=840$

$\alpha$-predikat $_{7} \quad=\min \left(\mu_{\text {jualBanyak }}[180] ; \mu_{\text {sisaBanyak }}[289]\right.$; $\left.\mu_{\text {covidBerkurang }}[6]\right)$

$=\min (0 ; 0 ; 1)$

$=0$

$\mathrm{Z}_{7}$

$$
=840
$$

[R8] IF Penjualan Banyak AND Sisa Penjualan Banyak

AND Covid-19 Bertambah THEN Produksi $=720$

$\alpha$-predikat $_{8} \quad=\min \left(\mu_{\text {jualBanyak }}[180] ; \mu_{\text {sisaBanyak }}[289]\right.$;

$$
\left.\mu_{\text {covidBertambah }}[6]\right)
$$$$
=\min (0 ; 0 ; 0)
$$$$
=0
$$

$\mathrm{Z}_{8}$

$$
=720
$$

$\begin{array}{lll}\text { 17-Apr-20 } & 540 & 576 \\ \text { 18-Apr-20 } & 285 & 270 \\ \text { 19-Apr-20 } & 495 & 390 \\ 20-A p r-20 & 555 & 576\end{array}$

\subsection{Analisis Penegasan Fuzzy Menggunakan Matlab}

Penegasan jumlah produksi yang diprediksi menggunakan metode fuzzy Takagi-Sugeno dapat dilakukan menggunakan Tools Fuzzy Matlab versi R2019a. Software ini memiliki fungsi untuk menghitung nilai variabel jumlah produksi roti pada Global Bakery berdasarkan data penjualan, sisa penjualan, dan data Covid-19. Adapun tahapan membangun sistem penegasan yang dilakukan pada penelitian ini menggunakan Matlab R2019a sebagai berikut:

Pertama, pembentukan variabel input jual, sisa, dan covid serta variabel output yaitu produksi pada jendela Fuzzy Inference System (FIS) Editor. Gambar 9 menunjukkan tiga input yang berwarna kuning yaitu jual, sisa, dan Covid, sedangkan yang berwarna biru yaitu output jumlah produksi.

Kemudian menghitung defuzzifikasi pengujian data tanggal 20 Maret 2020,

$$
\begin{aligned}
& \text { tanggal 20 Maret 2020, } \\
& z=\frac{0,056 * 347,3+0 * 270+\cdots+0 * 840+0 * 720}{0,056} \\
& \quad=\frac{19,294}{0,056}=347,3
\end{aligned}
$$

\begin{tabular}{|c|c|c|}
\hline Tanggal & $\begin{array}{c}\text { Data Aktual } \\
\text { Produksi }\end{array}$ & $\begin{array}{c}\text { Hasil Perhitungan } \\
\text { Manual }\end{array}$ \\
\hline 20-Mar-20 & 469 & 347,3 \\
\hline 21-Mar-20 & 432 & 330,2 \\
\hline 22-Mar-20 & 544 & 330,2 \\
\hline 23-Mar-20 & 479 & 589,2 \\
\hline 24-Mar-20 & 371 & 347,3 \\
\hline 25-Mar-20 & 265 & 347,3 \\
\hline 26-Mar-20 & 310 & 347,3 \\
\hline 27-Mar-20 & 216 & 347,3 \\
\hline 28-Mar-20 & 651 & 589,2 \\
\hline 29-Mar-20 & 255 & 330,2 \\
\hline $30-M a r-20$ & 630 & 589,2 \\
\hline 31-Mar-20 & 225 & 347,3 \\
\hline 1-Apr-20 & 570 & 589,2 \\
\hline 2-Apr-20 & 570 & 589,2 \\
\hline 3-Apr-20 & 840 & 840,0 \\
\hline 4-Apr-20 & 525 & 589,2 \\
\hline 5-Apr-20 & 420 & 330,2 \\
\hline 6-Apr-20 & 435 & 589,2 \\
\hline 7-Apr-20 & 285 & 347,3 \\
\hline 8-Apr-20 & 435 & 270,0 \\
\hline 9-Apr-20 & 330 & 270,0 \\
\hline 10-Apr-20 & 630 & 576,0 \\
\hline 11-Apr-20 & 720 & 720,0 \\
\hline 12-Apr-20 & 285 & 390,0 \\
\hline 13-Apr-20 & 555 & 576,0 \\
\hline 14-Apr-20 & 300 & 270 \\
\hline 15-Apr-20 & 600 & 576 \\
\hline 16-Apr-20 & 225 & 270 \\
\hline
\end{tabular}

Jadi, jumlah roti yang harus diproduksi sebanyak 347,3 dibulatkan menjadi 347 buah.

Perhitungan manual dilakukan hingga pengujian ke 32 dan didapatkan hasil seperti pada Tabel 5.

Tabel 5. Hasil perhitungan manual fuzzy Takagi-Sugeno

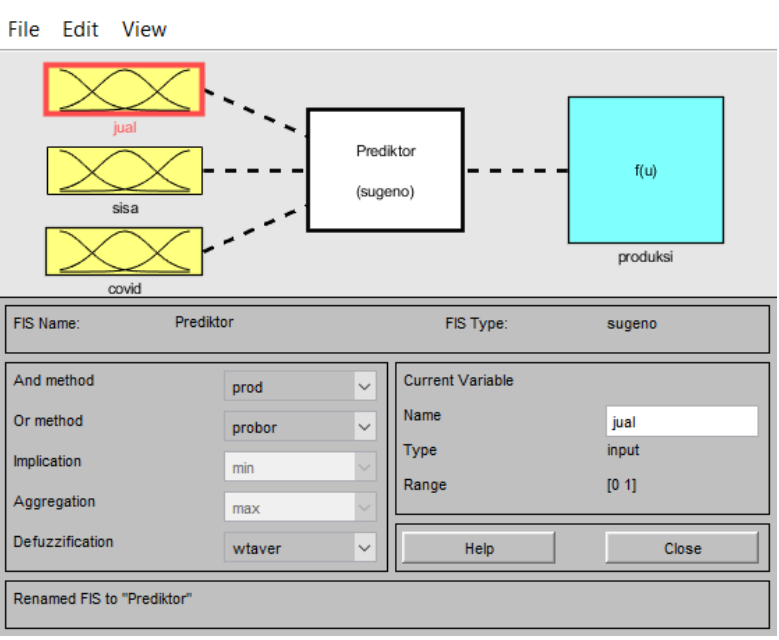

Gambar 9. Penerapan variabel ke dalam Matlab

Kedua, membentuk himpunan fuzzy dan fungsi keanggotaan dengan pilih salah satu varibel yang berwarna kuning pada tampilan Gambar 9.

Klik dua kali pada variabel yang berwarna kuning, kemudian masukkan nilai semesta pembicaraan pada kolom range, lalu masukkan nilai domain pada kolom params pada jendela Membership Function Editor. Variabel jual, membentuk himpunan fuzzy sedikit dan banyak dengan range [50 400], himpunan fuzzy sedikit untuk membentuk fungsi keanggotaan tipe variabelnya adalah trapmf dengan parameter $\left[\begin{array}{llll}50 & 50 & 90 & 220\end{array}\right]$. Himpunan fuzzy banyak untuk membentuk fungsi keanggotaan tipe variabelnya trampf dengan parameter $\left[\begin{array}{llll}220 & 350 & 400 & 400\end{array}\right]$. Hasil pembentukan fungsi keanggotaan variabel jual seperti pada Gambar 10.

DOI: https://doi.org/10.29207/resti.v5i2.2973

Lisensi: Creative Commons Attribution 4.0 International (CC BY 4.0) 


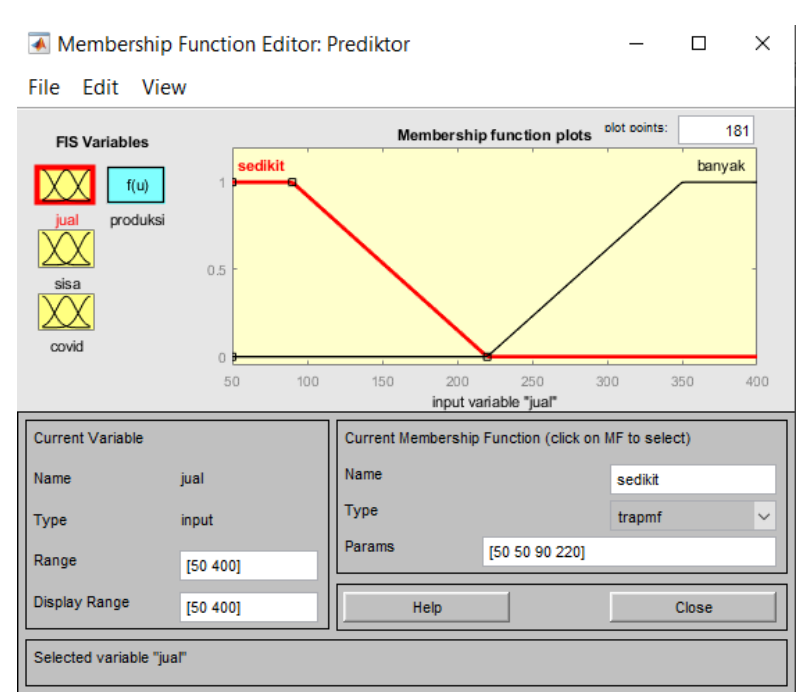

Gambar 10. Fungsi keanggotaan variabel input jual

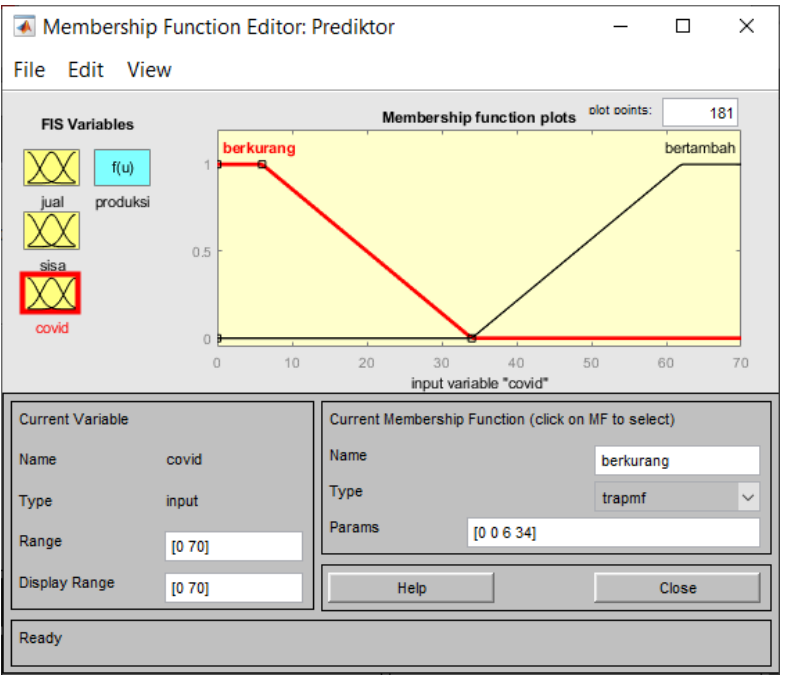

Gambar 12. Fungsi keanggotaan variabel input covid

Variabel sisa memiliki himpunan fuzzy sedikit dan Pembentukan himpunan untuk variabel output produksi, banyak dengan range [0 650], himpunan fuzzy sedikit memiliki himpunan fuzzy sedikit dan banyak. Himpunan untuk membentuk fungsi keanggotaan tipe variabelnya fuzzy dengan tipe variabel constant memiliki range [200 adalah trapmf dengan parameter $\left[\begin{array}{llll}0 & 0 & 0 & 306\end{array}\right]$, dan 850] terbagi menjadi 8 fungsi keanggotaan. Fungsi himpunan fuzzy banyak untuk membentuk fungsi keanggotaan yang terbentuk pada variabel produksi keanggotaan tipe variabelnya adalah trapmf dengan masing-masing diberi nama R1 dengan parameter parameter [306 612650 650]. Hasil seperti pada Gambar [347,3], R2 dengan parameter [270], R3 dengan 11. parameter [589,2], R4 dengan parameter [576], R5

A Membership Function Editor: Prediktor File Edit View

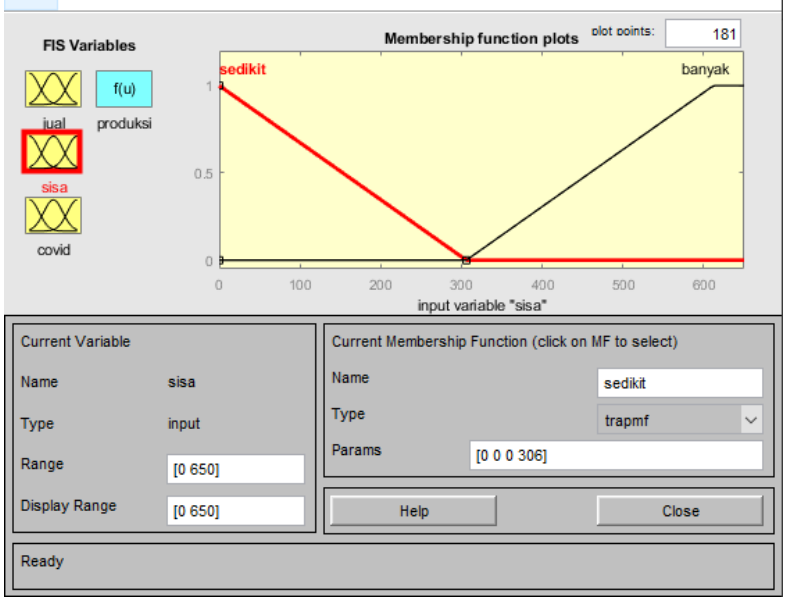

Gambar 11. Fungsi keanggotaan variabel input sisa

Variabel covid memiliki himpunan fuzzy berkurang dan bertambah dengan range [0 70], himpunan fuzzy berkurang untuk membentuk fungsi keanggotaan tipe variabelnya trapmf dengan parameter $\left[\begin{array}{llll}0 & 0 & 6 & 34\end{array}\right]$ dan himpunan fuzzy bertambah untuk membentuk fungsi keanggotaan tipe variabelnya adalah trapmf dengan parameter [34 6270 70]. Hasil pembentukan fungsi keanggotaan variabel covid seperti pada Gambar 12. dengan parameter [330,2], R6 dengan parameter [390], R7 dengan parameter [840], dan R8 dengan parameter [720]. Parameter-parameter tersebut seperti yang sudah ditentukan pada Gambar 13.

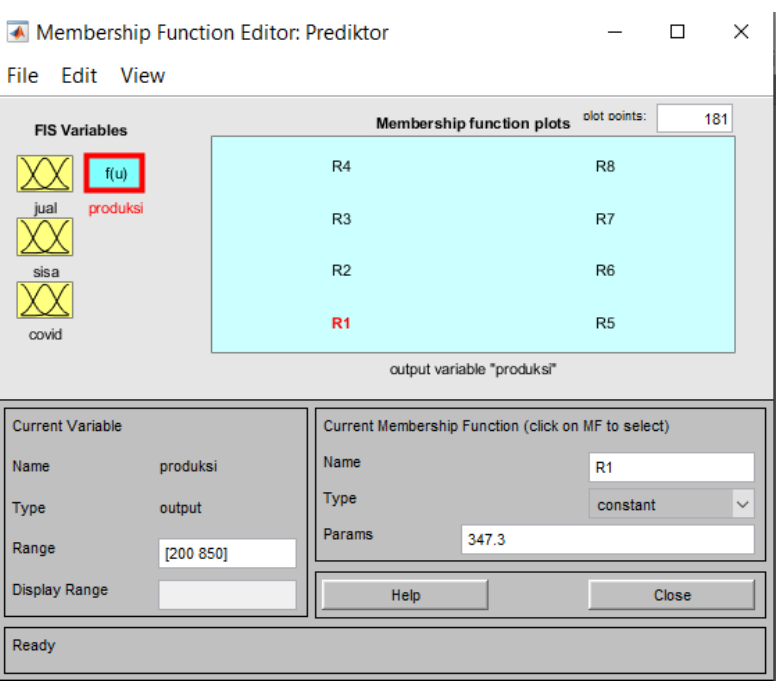

Gambar 13. Fungsi keanggotaan variabel produksi

Ketiga, menyusun aturan fuzzy berdasarkan aturan yang sudah ditentukan pada poin 3.1 mengenai tahapan pembentukan aturan. Berikut hasil penyusunan aturan disajikan pada Gambar 14. 


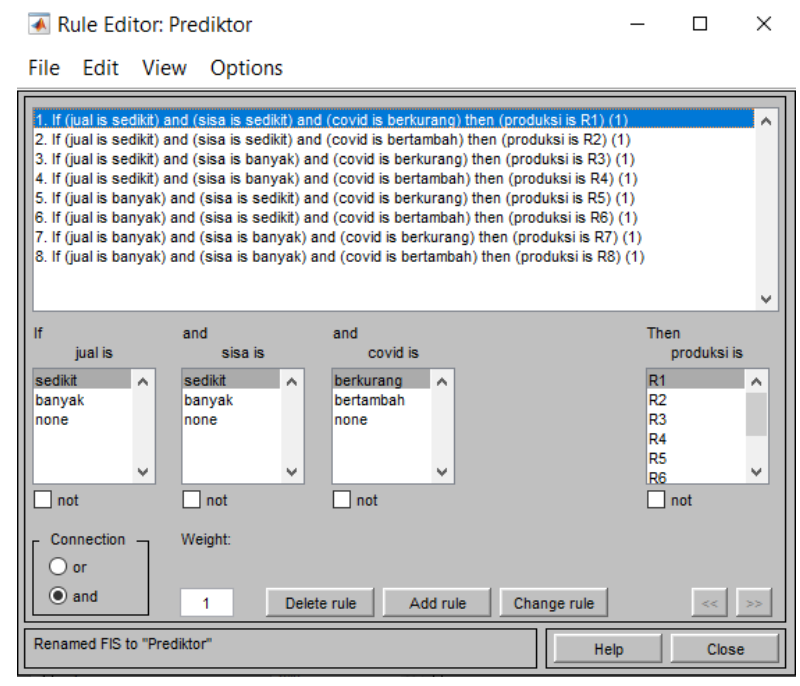

Gambar 14. Aturan fuzzy berdasarkan variabel linguistik

Keempat, melakukan optimasi pada jendela Rule View dengan menggunakan data jual, sisa, dan covid seperti pada Tabel 2 maka akan diketahui berapa jumlah roti yang harus diproduksi. Sebagai contoh, input penjualan sebanyak 114, input sisa sebanyak 441, dan input covid sebanyak 62 maka akan muncul jumlah produksi oleh sistem fuzzy Sugeno sebanyak 576 buah. Hasil tampilan terlihat pada Gambar 15.

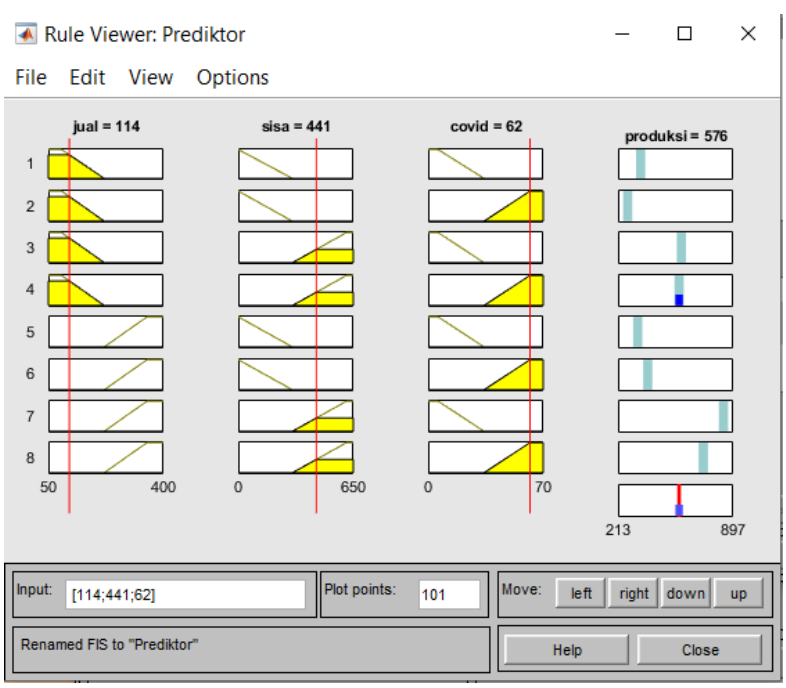

Gambar 15. Hasil optimasi melalui Rule View dengan jumlah jual 114, sisa 441, dan covid 62

Tahap berikutnya yaitu menerapkan Fuzzy TakagiSugeno pada software Prediktor jumlah produksi menggunakan Guide Matlab R2019a, software Prediktor dibangun untuk mempermudah dan memberikan gambaran simulasi yang berbentuk software sebagai alat bantu dalam memprediksi jumlah produksi roti pada Global Bakery. Berikut merupakan tampilan software yang telah dibangun dalam penelitian ini seperti pada Gambar 16.

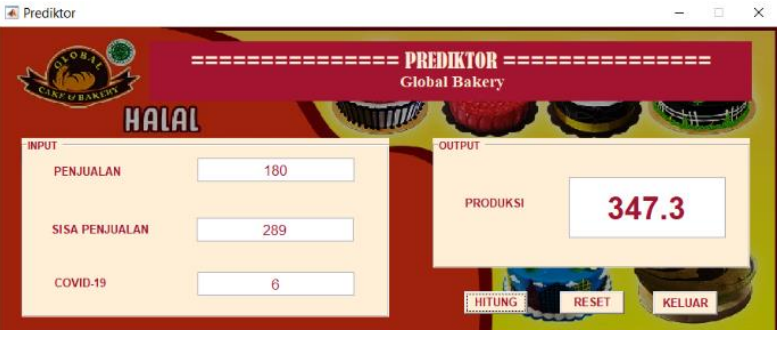

Gambar 16. Tampilan software Prediktor

Gambar 16 menunjukkan program GUI Prediktor, dimana program tersebut akan menampilkan output berupa nilai hasil perhitungan prediksi jumlah produksi roti. Perhitungan produksi ditentukan oleh 3 variabel inputan yang berdasarkan kriteria yang sudah ditetapkan. Program tersebut dibangun menggunakan tools Matlab dengan fungsi logika AND. Berikut dari 32 data yang dihitung menggunakan program Prediktor didapat hasil pada Tabel 6.

Tabel 6. Hasil perhitungan fuzzy Takagi-Sugeno menggunakan Matlab

\begin{tabular}{ccc}
\hline Tanggal & $\begin{array}{c}\text { Data Aktual } \\
\text { Produksi }\end{array}$ & $\begin{array}{c}\text { Hasil Perhitungan } \\
\text { Matlab }\end{array}$ \\
\hline 20-Mar-20 & 469 & 347,3 \\
21-Mar-20 & 432 & 330,2 \\
22-Mar-20 & 544 & 330,2 \\
23-Mar-20 & 479 & 589,2 \\
24-Mar-20 & 371 & 347,3 \\
25-Mar-20 & 265 & 347,3 \\
26-Mar-20 & 310 & 347,3 \\
27-Mar-20 & 216 & 347,3 \\
28-Mar-20 & 651 & 589,2 \\
29-Mar-20 & 255 & 330,2 \\
30-Mar-20 & 630 & 589,2 \\
31-Mar-20 & 225 & 347,3 \\
1-Apr-20 & 570 & 589,2 \\
2-Apr-20 & 570 & 589,2 \\
3-Apr-20 & 840 & 840,0 \\
4-Apr-20 & 525 & 589,2 \\
5-Apr-20 & 420 & 330,2 \\
6-Apr-20 & 435 & 589,2 \\
7-Apr-20 & 285 & 347,3 \\
8-Apr-20 & 435 & 270,0 \\
9-Apr-20 & 330 & 270,0 \\
10-Apr-20 & 630 & 576,0 \\
11-Apr-20 & 720 & 720,0 \\
12-Apr-20 & 285 & 390,0 \\
13-Apr-20 & 555 & 576,0 \\
14-Apr-20 & 300 & 270 \\
15-Apr-20 & 600 & 576 \\
16-Apr-20 & 225 & 270 \\
17-Apr-20 & 540 & 576 \\
18-Apr-20 & 285 & 390 \\
19-Apr-20 & 495 & 576 \\
20-Apr-20 & 555 & \\
\hline & & \\
\hline
\end{tabular}

\subsection{Evaluasi}

Hasil perhitungan manual dan hasil perhitungan menggunakan software Prediktor memiliki nilai yang sama besar. Nilai prediksi dengan nilai aktual kemudian dilakukan evaluasi menggunakan Mean Absolute Percentage Error (MAPE). Tabel 7 menunjukkan perhitungan nilai MAPE. 
Tabel 7. Perbandingan penerapan logika fuzzy Takagi-Sugeno

\begin{tabular}{|c|c|c|c|c|c|}
\hline Tanggal & $\begin{array}{c}\text { Nilai } \\
\text { aktua } \\
1 \\
(y t)\end{array}$ & $\begin{array}{c}\text { Nilai } \\
\text { prediksi } \\
(\hat{y} t)\end{array}$ & $\begin{array}{c}\text { Error } \\
(\hat{y} t-y t)\end{array}$ & $\begin{array}{c}\text { Absolute } \\
\text { Error } \\
|\hat{y} t-y t|\end{array}$ & $\begin{array}{c}\text { Absolute } \\
\text { error } \\
\text { divided } \\
\text { by } \\
\text { actual } \\
\text { value } \\
|\hat{y} t-y t|\end{array}$ \\
\hline & & & & & $y t$ \\
\hline 20-Mar-20 & 469 & 347.3 & $-121,7$ & 121,7 & 0,259 \\
\hline 21-Mar-20 & 432 & 330.2 & $-101,8$ & 101,8 & 0,236 \\
\hline 22-Mar-20 & 544 & 330.2 & $-213,8$ & 213,8 & 0,393 \\
\hline 23-Mar-20 & 479 & 589.2 & 110,2 & 110,2 & 0,230 \\
\hline 24-Mar-20 & 371 & 347.3 & $-23,7$ & 23,7 & 0,064 \\
\hline 25-Mar-20 & 265 & 347.3 & 82,3 & 82,3 & 0,311 \\
\hline 26-Mar-20 & 310 & 347.3 & 37,3 & 37,3 & 0,120 \\
\hline 27-Mar-20 & 216 & 347.3 & 131,3 & 131,3 & 0,608 \\
\hline 28-Mar-20 & 651 & 589.2 & $-61,8$ & 61,8 & 0,095 \\
\hline 29-Mar-20 & 255 & 330.2 & 75,2 & 75,2 & 0,295 \\
\hline 30-Mar-20 & 630 & 589.2 & $-40,8$ & 40,8 & 0,065 \\
\hline 31-Mar-20 & 225 & 347.3 & 122,3 & 122,3 & 0,544 \\
\hline 1-Apr-20 & 570 & 589.2 & 19,2 & 19,2 & 0,034 \\
\hline 2-Apr-20 & 570 & 589.2 & 19,2 & 19,2 & 0,034 \\
\hline 3-Apr-20 & 840 & 840 & 0 & 0 & 0 \\
\hline 4-Apr-20 & 525 & 589.2 & 64,2 & 64,2 & 0,122 \\
\hline 5-Apr-20 & 420 & 330.2 & $-89,8$ & 89,8 & 0,214 \\
\hline 6-Apr-20 & 435 & 589.2 & 154,2 & 154,2 & 0,354 \\
\hline 7-Apr-20 & 285 & 347.3 & 62,3 & 62,3 & 0,219 \\
\hline 8-Apr-20 & 435 & 270 & -165 & 165 & 0,379 \\
\hline 9-Apr-20 & 330 & 270 & -60 & 60 & 0,182 \\
\hline 10-Apr-20 & 630 & 576 & -54 & 54 & 0,086 \\
\hline 11-Apr-20 & 720 & 720 & 0 & 0 & 0 \\
\hline 12-Apr-20 & 285 & 390 & 105 & 105 & 0,368 \\
\hline 13-Apr-20 & 555 & 576 & 21 & 21 & 0,038 \\
\hline 14-Apr-20 & 300 & 270 & -30 & 30 & 0,100 \\
\hline 15-Apr-20 & 600 & 576 & -24 & 24 & 0,040 \\
\hline 16-Apr-20 & 225 & 270 & 45 & 45 & 0,200 \\
\hline 17-Apr-20 & 540 & 576 & 36 & 36 & 0,067 \\
\hline 18-Apr-20 & 285 & 270 & -15 & 15 & 0,053 \\
\hline 19-Apr-20 & 495 & 390 & -105 & 105 & 0,212 \\
\hline 20-Apr-20 & 555 & 576 & 21 & 21 & 0,038 \\
\hline Total & $\begin{array}{c}1444 \\
7\end{array}$ & 14446 & -1 & 2212,1 & 5,958 \\
\hline$n$ & 32 & & & & \\
\hline MAPE (\%) & $\begin{array}{c}18,61 \\
8 \%\end{array}$ & & & & \\
\hline
\end{tabular}

Berdasarkan hasil perhitungan pada Tabel 7 diperoleh nilai MAPE sebesar $18,6 \%$ menunjukkan bahwa prediksi menggunakan metode logika Fuzzy TakagiSugeno termasuk penilaian BAIK. Hal tersebut menunjukkan bahwa metode Fuzzy Takagi-Sugeno mampu digunakan untuk membantu menentukan banyaknya roti yang akan diproduksi oleh Global Bakery.

\section{Kesimpulan}

Berdasarkan pembahasan mengenai logika Fuzzy Takagi-Sugeno yang telah dilakukan, dapat diambil kesimpulan bahwa hasil perhitungan prediksi yang ditampilkan pada program Prediktor dapat dijadikan alternatif penentu jumlah roti yang akan diproduksi pada hari berikutnya saat pandemi Covid-19. Metode Fuzzy Takagi-Sugeno mampu memprediksi jumlah produksi roti pada Global Bakery dengan hasil yang optimal, dimana jika penjualan sebanyak 180 buah, sisa penjualan sebanyak 289 buah, dan jumlah kasus positif Covid-19 sebanyak 6 orang dengan jumlah produksi aktual sebanyak 469 buah, maka diperoleh hasil prediksi jumlah produksi sebanyak 347 buah. Hasil prediksi jumlah produksi roti menggunakan metode Fuzzy Takagi-Sugeno mendapatkan nilai MAPE sebesar 18,6\%. Nilai MAPE 18,6\% dapat dikatakan memiliki akurasi yang baik.

\section{Daftar Rujukan}

[1] S. Yezli and A. Khan, "COVID-19 social distancing in the Kingdom of Saudi Arabia: Bold measures in the face of political, economic, social and religious challenges," $J$. Elsevier, no. January, 2020.

[2] C. Sohrabi et al., "World Health Organization declares global emergency: A review of the 2019 novel coronavirus ( COVID19 )," Int. J. Surg., vol. 76, no. February, pp. 71-76, 2020.

[3] Kementerian Kesehatan Republik Indonesia, "Penetapan Pembatasan Sosial Berskala Besar di Wilayah Kabupaten Bogor, Kota Bogor, Kota Depok, Kabupaten Bekasi, dan Kota Bekasi, Provinsi Jawa Barat dalam Rangka Percepatan Penanganan Coronavirus Disease 2019 (Covid-19)," 2020.

[4] A. Weber, F. Iannelli, and S. an Gon calves, "Trend Analysis of The COVID-19 Pandemic In China And The Rest of The World," 2020.

[5] A. M. Al-awadhi, K. Alsaifi, A. Al-awadhi, and S. Alhammadi, "Death and Contagious Infectious Diseases: Impact Of The COVID-19 Virus On Stock Market Returns," J. Behav. Exp. Financ., vol. 27, p. 100326, 2020, doi: 10.1016/j.jbef.2020.100326.

[6] W. Hadiwardoyo, "Kerugian Ekonomi Nasional Akibat Pandemi Covid-19," Baskara J. Bus. Entrep., vol. 2, no. 2, pp. 83-92, 2020, doi: 10.24853/baskara.2.2.83-92.

[7] L. Costaner and G. Wenny Syafitri, "Optimasi Jumlah Produksi Usaha Dagang Roti Prima Sari Menggunakan Metode Logika Fuzzy," J. Sist. Inf., vol. 8, no. September, pp. 424-435, 2019.

[8] S. Pinontoan, I. A. Musdar, and Hasniati, "Penerapan Logika Fuzzy Metode Sugeno Untuk Menentukan Jumlah Produksi Roti Berdasarkan Data Persediaan Dan Jumlah Permintaan (Studi Kasus: Pabrik Roti Sarinda Ambon)," J. Ilmu Mat. dan Terap., vol. 9, pp. 121-134, 2015.

9] X. Liu, S. Member, Z. Gao, S. Member, M. Z. Q. Chen, and S. Member, "Takagi - Sugeno Fuzzy Model Based Fault Estimation and Signal Compensation With Application to Wind Turbines," IEEE Trans. Ind. Electron., vol. 64, no. 7, pp. 56785689, 2017, doi: 10.1109/TIE.2017.2677327.

[10] D. M. Efendi and F. A. Ardhy, "Perbandingan Metode Fuzzy Inferensi Tsukamoto Dan Sugeno Untuk Memprediksi Pemesanan Roti Jordan," J. Tekno Kompak, vol. 12, no. 2, p. 45, 2018, doi: $10.33365 /$ jtk.v12i2.147.

11] S. Surhajito, J. Jimmy, and A. S. Girsang, "Mobile decision support system to determine Toddler's nutrition using fuzzy sugeno," Int. J. Electr. Comput. Eng., vol. 7, no. 6, pp. 36833691, 2017, doi: 10.11591/ijece.v7i6.pp3683-3691.

[12] A. Ahmad, "Penerapan Sistem Inferensi Fuzzy Dengan Metode Sugeno Dalam Memperkirakan Produksi Gula," vol. im, no. 2007, p. 3083, 2016.

[13] J. Warmansyah and D. Hilpiah, "Penerapan metode fuzzy sugeno untuk prediksi persediaan bahan baku," Teknois J. Ilm. Teknol. Inf. dan Sains, vol. 9, no. 2, pp. 12-20, 2019, doi: 10.36350/jbs.v9i2.58.

[14] A. Singh, N. Kashyap, and R. Garg, "Fuzzy based approach for diet prediction," Proc. 9th Int. Conf. Cloud Comput. Data Sci. Eng. Conflu. 2019, pp. 377-381, 2019, doi: 10.1109/CONFLUENCE.2019.8776917.

[15] S. Kusumadewi and H. Purnomo, "Aplikasi Logika Fuzzy untuk Pendukung Keputusan,” 2nd ed., Yogyakarta, 2013, pp. 1-75.

[16] S. Pinontoan, I. A. Musdar, and Hasniati, "Perbandingan 
Metode Fuzzy Sugeno Dengan Fuzzy Tsukamoto Pada Sistem [19] Prediksi Harga Smartphone Bekas Berbasis Android Di Wilayah Makassar,” J. Ilmu Komput., pp. 34-42, 2019.

[17] X. I. N. Tang and D. Ning, "A Takagi-Sugeno Fuzzy ModelBased Control Strategy for Variable Stiffness and Variable Damping Suspension," IEEE Access, vol. 8, pp. 71628-71641, 2020, doi: 10.1109/ACCESS.2020.2983998.

[18] A. I. Fahrika and J. Roy, "Dampak pandemi covid 19 terhadap perkembangan makro ekonomi di indonesia dan respon kebijakan yang ditempuh The impact of the Covid 19 pandemic on macroeconomic developments in Indonesia and the policy response taken," J. Ekon. Keuang. dan Manaj., vol. 16, no. 2, pp. 206-213, 2020.
19] M. Irfan, L. P. Ayuningtias, and J. Jumadi, "Analisa Perbandingan Logic Fuzzy Metode Tsukamoto, Sugeno, Dan Mamdani ( Studi Kasus : Prediksi Jumlah Pendaftar Mahasiswa Baru Fakultas Sains Dan Teknologi Uin Sunan Gunung Djati Bandung)," J. Tek. Inform., vol. 10, no. 1, pp. 9-16, 2018, doi: 10.15408/jti.v10i1.6810.

[20] Laras Purwati Ayuningtias, Mohamad irfan, and Jumadi, "Analisa Perbandingan Logic Fuzzy Metode Tsukamoto, Sugeno, Dan Mamdani (Studi Kasus: Prediksi Jumlah Pendaftar Mahasiswa Baru Fakultas Sains Dan Teknologi Universitas Islam Negeri Sunan Gunung Djati Bandung),' $J$. Tek. Inform., vol. 10, pp. 9-16, 2017. 